\title{
PENERAPAN METODE MIND MAPPING UNTUK MENINGKATKAN KREATIVITAS PADA PEMBELAJARAN PENDIDIKAN KEWARGANEGARAAN
}

\author{
Heri Hidayat 1), Heny Mulyani 2), Ajeng Siti Fatimah 3), \\ Amallia Sholihat ${ }^{4)}$, Ana Zulfia Latifah 5) \\ Universitas Islam Negeri Sunan Gunung Djati Bandung \\ e-mail: \\ 1) herihidayat@uinsgd.ac.id, 2) henymulyani@uinsgd.ac.id, \\ 3) ajengfatimah91@gmail.com, 4) amalliasholihat@gmail.com, \\ 5) zulfia.latifah@gmail.com
}

\begin{abstract}
In learning, we need a method to enhance the creativity of the students, one of them with Mind Mapping method. This study aims to explain the application of mind mapping methods to increase creativity in learning Citizenship Education in Class VI Madrasah Ibtidaiyah (MI). This research was conducted using field observation of 25 students. The Research Data collection is based on the results of students learning activities to create a mind map. The results showed that the Mind Mapping method can enhance students' creativity in studying Pancasila and Citizenship Education.
\end{abstract}

Keywords: mind mapping, creativity, citizenship education.

Abstrak: Dalam Pembelajaran, diperlukan sebuah metode untuk meningkatkan kreativitas siswa, salah satunya dengan metode Mind mapping. Penelitian ini bertujuan untuk mengetahui bagaimana penerapan metode mind mapping untuk meningkatkan kreativitas pada pembelajaran Pendidikan Kewarganegaraan di Kelas VI MI. Penelitian ini dilakukan dengan observasi ke lapangan yang dilakukan di kelas VI MI Miftahul Falah dengan jumlah 25 siswa. Pengambilan data dilakukan melalui hasil kegiatan belajar dengan membuat sebuah mind mapping. Hasil penelitian menunjukkan bahwa metode Mind mapping dapat meningkatkan kreativitas siswa pada pembelajaran Pendidikan Pancasila dan Kewarganegaraan.

Kata kunci: mind mapping, kreativitas, pendidikan kewarganegaran. 


\section{PENDAHULUAN}

Melalui Kementrian Pendidikan dan Kebudayaan, pemerintah Indonesia berupaya untuk melakukan perbaikan dalam hal mutu pendidikan. Menurut Wulandari, dkk (2019) sebuah kurikulum yang berlaku di Indonesia yakni Kurikulum 2013, dimana kurikulum tersebut pengganti dari kurikulum sebelumnya yaitu Kurikulum 2006 atau KTSP (Kurikulum Tingkat Satuan Pendidikan). Implementasi Kurikulum 2013 (K13) merupakan suatu kebijakan yang diambil oleh Kementrian Pendidikan dan Kebudayaan dimana berlaku pada tahun 2014/2015 khususnya pada jenjang Sekolah Dasar sampai Sekolah Menengah Atas. Kurikulum 2013 yang sedang diberlakukan di Indonesia pelaksanaan pembelajarannya lebih menekankan pada proses pengembangan kognitif siswa yang kreatif selain itu juga siswa dituntut untuk berpikir kritis.

Mulyasa (2013), mengatakan bahwa pendidikan karakter terutama pada tingkat dasar yang merupakan sebuah pondasi untuk tingkat selanjutnya adalah ciri Kurikulum 2013. Melalui pengembangan Kurikulum 2013 yang berbasis karakter dan kompetensi kita mempunyai harapan bahwa kita bisa menjadi bangsa yang maju dan bermartabat dimana masyarakatnya memiliki nilai tambah dan nilai jual yang dapat kita tawarkannkepada orang lain, sehingga kita bisa bersaing dengan bangsa-bangsa lain di kancah global. Produktif, kreatif, inovatif dan berkarakter merupakan sebuah hasil dari implementasi Kurikulum 2013.

Suatu interaksi antara pendidik dan peserta didik dan sumber belajar pada suatu lingkungan belajar merupakan pembelajaran. Pembelajaran merupakan sebuah transfer ilmu pengetahuan yang terjadi antara pendidik dan peserta didik yang berupa pengetahuan, penguasaan kemahiran, pembentukan sikap dan kepercayaan kepada peserta didik. Guru atau pendidik memiliki peran yang sangat penting yaitu memberikan sejumlah ilmu pengetahuan kepada peserta didik dan menanamkan nilai-nilai dan sikap yang baik agar meiliki kepribadian yang baik bagi peserta didik.

Fauziah (2017) mengatakan bahwa belajar adalah suatu usaha perubahan dalam ilmu pengetahuan, sikap, dan keterampilannya untuk mempelajari sesuatu dari yang awalnya tidak tahu menjadi tahu. Selain itu juga proses pembelajaran harus ada interaksi yang positif antara guru dan siswa, posisi siswa tidak hanya menerima ilmu pengetahuan saja, tetapi siswa juga harus mampu membangun sendiri ilmu pengetahuannya saat belajar.

Seorang guru dalam proses pembelajaran memiliki tugas dalam memilih model ataupun metode pembelajaran yang tepat untuk menyampaikam suatu materi pembelajaran agar tercapainya suatu tujuan dari pendidikan. Model pembelajaran adalah suatu perencanaan atau suatu pola yang digunakan sebagai pedoman dalam merencanakan pembelajaran di kelas atau pembelajaran dalam tutorial. Model pembelajaran mengacu pada pendekatan pembelajaran yang akan digunakan, termasuk di dalamnya tujuan pengajaran, tahap-tahap dalam kegiatan pembelajaran, lingkungan pembelajaran dan pengelolaan kelas.

Berdasarkan latar belakang masalah yang telah dibahas sebelumnya, penelitian ini kemudian mengacu pada 2 rumusan masalah sebagai berikut: 1) Bagaimana kreativitas siswa dalam pembelajaran PKn di kelas VI MI Miftahul Falah sebelum menggunakan metode mind mapping; 2) Bagaimana proses penerapan 
mind mapping untuk meningkatkan kreativitas siswa; 3) Bagaimana kreativitas siswa dalam pembelajaran PKn di kelas VI MI Miftahul Falah setelah menggunakan metode mind mapping.

Model pembelajaran berfungsi sebagai pedoman bagi perancang dan para guru dalam melaksanakan pembelajaran. Untuk pemilihan model ini sangat dipengaruhi dari sifat dan materi yang akan diajarakan, juga dipengaruhi oleh tujuan yang akan dicapai dalam pengajaran tersebut serta tingkat kemampuan peseta didik. Di samping itu pula, setiap model pembelajaran selalu mempunyai tahapantahapan (sintaks) oleh peserta didik dengan bimbingan guru. Antara sintaks yang satu dengan sintaks yang lain juga mempunyai perbedaan. Perbedaan-perbedaan ini berlangsung di antara pembukaan dan penutup yang harus dipahami oleh guru supaya model-model pembelajaran dapat dilaksanakan dengan berhasil .

Menurut Prastyo (2016) salah satu cara yang dilakukan dalam menyampaikan pembelajaran yaitu metode. Kendala tidak tercapainya sebuah tujuan pembelajaran tergantung pada penggunaan metode yang tidak sesuai dengan tujuan. Seorang guru dituntut untuk membuat proses pembelajaran menarik dengan menggunakan metode yang akan membuat peserta didik terlibat dalam pembelajaran dan berkreativitas. Pemilihan metode harus disesuaikan dengan materi yang diajarkan, kondisi sekolah, dan kondisi peserta didik dan penyesuaian lainnya. Karena jika kita salah memilih metode yang tidak sesuai akan berdampak pada hasil yang kurang maksimal.

Mind mapping merupakan salah satu metode pembelajaran dimana siswa mampu menjadi kreatif dalam menghasilkan suatu gagasan atau pikiran, mencatat apa yang harus dipelajari. Metode ini lebih menekankan pada pengkombinasian warna dan bentuk yang akan membuat siswa semakin tertarik dan bersemangat dalam proses pembelajaran, sehingga materi yang diserap dapat mudah dipahami. Mind mapping merupakan metode yang dapat digunakan untuk mengembangkan kreativitas belajar siswa. Darusman (2014) menyatakan bahwa metode pembelajaran mind mapping adalah metode pembelajaran yang dirancang untuk mengembangkan siswa dengan kreatif menyusun ide-ide pokok dari sebuah konsep menjadi sebuah peta pikiran yang mudah dipahami oleh siswa.

Sitepu (2019) menjelaskan kreativitas masih dipandang sebagai bagian besar dari aktivitas dan produk dari bidang seni, meskipun kenyataannya, kreativitas bukan hanya dimiliki oleh para seniman belaka tetapi semua bidang membutuhkan kreativitas, termasuk dalam bidang pendidikan. Lembaga pendidkan memiliki peran penting dalam membangun kreativitas peseta didiknya para guru harusnya dapat melakukan pembinaan kreativitas terhadap peserta didik jika para guru sudah membiasakan diri untuk memiliki sifat kreatif. Maka dari itu dalam sebuah proses pembelajaran dibutuhkan suatu cara/strategi yang dapat membantu menunjang kegiatan belajar mengajar agar tujuan pembelajaran dapat tercapai secara maksimal.

Kreativitas merupakan kemampuan seseorang untuk menciptakan sesuatu yang baru dan hasil dari sebuah kombinasi inovasi yang membuat seseorang memiliki kemampuan berpikir secara imaginatif. Pada hakikatnya, kreativitas dimiliki oleh setiap individu yang dapat dikaitkan dengan prestasi dalam menciptakan sesuatu yang baru maupun yang sudah ada menjadi sebuah konsep baru dan 
belum pernah ada. Selain itu, kreativitas juga adalah kemampuan yang dimiliki oleh seseorang dalam menghasilkan gagasan yang baru dan dapat dikembangkan. Betaubun, dkk., (2018) mengatakan bahwa kreativitas sangat penting dimiliki oleh siswa karena merupakan suatu keterampilan diri yang bermanfaat dalam kehidupan sehari-hari dan dalam proses pembelajaran. Siswa yang memiliki kreativitas tinggi dapat menyelesaikan persoalannya dalam proses belajar, sehingga dengan kreativitasnya dapat meningkatkan hasil belajar siswa.

Berdasarkan latar belakang tersebut, maka tujuan penelitian adalah untuk menganalisis penerapan metode mind mapping untuk meningkatkan kreativitas pada pembelajaran pendidikan kewarganegaraan di kelas VI MI yang dilakukan di MI Miftahul Falah kota Bandung.

\section{METODE}

Penelitian ini menggunakan metode deskriptif kuantitatif. Menurut Hermawan (2019) metode deskriptif adalah metode penelitian, dimana dalam mengumpulkan data dilakukan dengan menguji pertanyaan penelitiaan yang berkaitan dengan keadaan dan kejadian sekarang. Selain itu juga, metode penelitian ini dilakukan dengan tujuan utama untuk membuat gambaran atau deskripsi tentang suatu keadaan secara sistematis, akurat, dan aktual yang ada hubungannya dengan masalah yang diteliti yaitu menerapkan metode mind mapping untuk meningkatkan kreativitas pada pembelajaran Pendidikan Kewarganegaraan di kelas VI MI.

MI Miftahul Falah 1 merupakan sekolah madrasah yang memiliki visi "Terbentuknya Pribadi Muslim Yang Sehat, Cerdas Dan TRAMPIL (Taqwa, Rajin, Amanah, Prestasi, Inovatif, Luas Wawasan) IMTAQ Dan IPTEK". Sekolah ini meliliki 1.340 siswa terdiri atas VI (enam) kelas. Dengan jumlah siswa yang cukup banyak maka MI Miftahul Falah membaginya menjadi dua bagian ada siswa yang sekolah pagi dan siang, kecuali kelas I (satu) tahun pelajaran 2018/2019 dibagi menjadi 4 (empat) kelas dengan jumlah siswa 143. Dalam penelitian ini data yang diambil dari sampel adalah data dari hasil pembelajaran siswa dengan menggunakan metode mind mapping melalui observasi yang terdiri dari 25 orang siswa kelas VI

\section{Instrumen Pengumpulan Data}

Teknik pengumpulan data menggunakan observasi dan penilaian kinerja siswa. Observasi digunakan bila penelitian berkenaan dengan perilaku manusia, proses kerja, dan bila responden yang diamati tidak terlalu besar. Untuk memperbaiki proses pembelajaran di kelas, dimulai dari munculnya permasalahanpermasalahan di dalam kelas yang dirasakan langsung oleh guru kemudian dilakukan suatu tindakan untuk mencapai suatu hasil yang maksimal. Indikator yang diukur dari kreativitas ini adalah kelacaran mengemukakan ide, keluwesan dalam mengajukan cara berbeda dalam memecahkan masalah, keaslian menghasilkan ide berdasarkan pemikiran sendiri dan menguraikan ide secara rinci (Yuniharto, $d k k$ : 2019). Selain itu juga kreatitivitas dapat dilihat dari pengetahuan dan keterampilan. Karena dengan menggunakan pengetahuan yang dimiliki dan ketrampilan berpikir, siswa dapat berpikir secara kreatif dengan cara pembelajaran yang bebas, terbuka, dan positif. Selain itu siswa juga dapat menghasilkan 
gambaran objek dan gagasan dengan cara-cara baru, memecahkan masalah, menghasilkan ide-ide atau gagasan yang unik. (Pamungkas, dkk: 2017). Proses kreatif memetakan ide dapat dituangkan di atas kertas baik berupa simbol, gambar, maupun tulisan. Pada akhirnya mind map yang telah dibuat siswa akan menunjukkan tingkatan kreativitasnya.

Penelitian ini dilaksanakan di MI Miftahul Falah Kota Bandung dengan jumlah siswa 25 orang di kelas $\mathrm{VI}$, yang terdiri dari 12 orang siswa perempuan dan 13 orang siswa laki-laki. Data dikumpulkan melalui hasil kegiatan belajar dengan membuat sebuah mind mapping untuk menunjang penilaian yang akan dilakukan. Proses kegiatan pembelajaran ini dilakukan dalam bentuk team teaching yang dilakukan oleh 2 orang guru. Pembelajaran pada awal kegiatan dilakukan oleh guru 1 dan proses pembelajaran kegiatan inti dilakukan oleh keduanya, dan penutupan dilakukan oleh guru 2. Proses pembelajaran dilakukan dengan membagi 5 kelompok siswa untuk mengembangkan mind map berdasarkan tes uraian yang diberikan guru dari materi yang sudah ditentukan.

Untuk menilai ketercapaian kreatifitas yang diukur dilakukan menggunakan indikator kreatifitas, seperti kelacaran mengemukakan ide, keluwesan dalam mengajukan cara berbeda untuk memecahkan masalah, keaslian ide berdasarkan pemikiran sendiri, dan menguraikan ide secara rinci yang diaplikasikan melalui gambar, warna, garis lengkung penghubung antara satu teks dan lainnya. Untuk mengukur ketercapaian indikator-indikator tersebut digunakan penilaian rubrik untuk pemberian nilai terhadap hasil mind map yang dibuat oleh siswa.

Tabel 1. Penilaian Rubrik Mind Mapping Kreatifitas Siswa

\begin{tabular}{|c|c|c|c|c|c|}
\hline \multirow[b]{2}{*}{$\begin{array}{l}\text { Aspek Yang } \\
\text { Diamati }\end{array}$} & \multirow[b]{2}{*}{ Indikator } & \multicolumn{4}{|c|}{ Penilaian } \\
\hline & & $\begin{array}{c}4 \\
\text { Sangat Kreatif }\end{array}$ & $\begin{array}{c}3 \\
\text { Kreatif }\end{array}$ & $\begin{array}{c}2 \\
\text { Cukup Kreatif }\end{array}$ & $\begin{array}{c}1 \\
\text { Kurang Kreatif }\end{array}$ \\
\hline Kelancaran & $\begin{array}{c}\text { Dapat melihat } \\
\text { masalah dari } \\
\text { berbagai sudut } \\
\text { pandang yang } \\
\text { berbeda }\end{array}$ & $\begin{array}{c}\text { Siswa } \\
\text { menganalisis } \\
\text { permasalahan } \\
\text { yang muncul dari } \\
\text { fakta dan } \\
\text { petunjuk yang } \\
\text { diberikan }\end{array}$ & $\begin{array}{c}\text { Siswa kurang } \\
\text { menganalisis } \\
\text { permasalahan yang } \\
\text { muncul dari fakta } \\
\text { dan petunjuk yang } \\
\text { diberikan guru }\end{array}$ & $\begin{array}{c}\text { Siswa hanya } \\
\text { menganalisis } \\
\text { permasalahan } \\
\text { yang muncul } \\
\text { dari penjelasan } \\
\text { guru saja atau } \\
\text { dari fakta saja }\end{array}$ & $\begin{array}{l}\text { Siswa tidak } \\
\text { menganalisis } \\
\text { permasalahan } \\
\text { yang muncul } \\
\text { dari fakta dan } \\
\text { petunjuk yang } \\
\text { diberikan guru }\end{array}$ \\
\hline Keluwesan & $\begin{array}{c}\text { Dapat } \\
\text { menerapkan } \\
\text { konsep, sifat, } \\
\text { atau aturan } \\
\text { dalam contoh } \\
\text { pemecahan } \\
\text { masalah }\end{array}$ & $\begin{array}{c}\text { Siswa dapat } \\
\text { menerapkan } \\
\text { konsep, sifat, } \\
\text { atau aturan } \\
\text { dalam praktikum } \\
\text { guna } \\
\text { memecahkan } \\
\text { permasalahan } \\
\text { dengan berbeda } \\
\text { dan tepat }\end{array}$ & $\begin{array}{l}\text { Siswa dapat } \\
\text { menerapkan } \\
\text { konsep, sifat, atau } \\
\text { aturan dalam } \\
\text { praktikum guna } \\
\text { memecahkan } \\
\text { permasalahan } \\
\text { dengan berbeda } \\
\text { namun kurang } \\
\text { tepat }\end{array}$ & $\begin{array}{c}\text { Siswa dapat } \\
\text { memecahkan } \\
\text { permasalahan } \\
\text { dengan berbeda } \\
\text { namun tidak } \\
\text { menerapkan } \\
\text { konsep, sifat } \\
\text { atau aturan } \\
\text { dalam } \\
\text { pelaksanaan }\end{array}$ & $\begin{array}{c}\text { Siswa tidak } \\
\text { menerapkan } \\
\text { konsep, sifat, } \\
\text { atau aturan } \\
\text { dalam praktikum } \\
\text { guna } \\
\text { memecahkan } \\
\text { permasalahan }\end{array}$ \\
\hline
\end{tabular}


Tabel 1. Lanjutan

\begin{tabular}{|c|c|c|c|c|c|}
\hline \multirow[b]{2}{*}{$\begin{array}{l}\text { Aspek Yang } \\
\text { Diamati }\end{array}$} & \multirow[b]{2}{*}{ Indikator } & \multicolumn{4}{|c|}{ Penilaian } \\
\hline & & $\begin{array}{c}4 \\
\text { Sangat Kreatif }\end{array}$ & $\begin{array}{c}3 \\
\text { Kreatif }\end{array}$ & $\begin{array}{c}2 \\
\text { Cukup Kreatif }\end{array}$ & $\begin{array}{c}1 \\
\text { Kurang Kreatif }\end{array}$ \\
\hline Keaslian & $\begin{array}{l}\text { Mencetuskan } \\
\text { masalah, } \\
\text { gagasan atau } \\
\text { hal-hal yag tak } \\
\text { terpikirkan } \\
\text { orang lain }\end{array}$ & $\begin{array}{c}\text { Siswa } \\
\text { mencetuskan } \\
\text { masalah, gagasan } \\
\text { atau hal yang } \\
\text { berbeda dengan } \\
\text { lancar dan tepat }\end{array}$ & $\begin{array}{c}\text { Siswa } \\
\text { mencetuskan } \\
\text { masalah, gagasan } \\
\text { atau hal yang } \\
\text { berbeda dengan } \\
\text { lancar namun } \\
\text { kurang tepat }\end{array}$ & $\begin{array}{c}\text { Siswa } \\
\text { mencetuskan } \\
\text { masalah, } \\
\text { gagasan atau hal } \\
\text { yang berbeda } \\
\text { dengan tidak } \\
\text { lancar dan tidak } \\
\text { tepat }\end{array}$ & $\begin{array}{c}\text { Siswa tidak } \\
\text { mencetuskan } \\
\text { masalah, } \\
\text { gagasan atau hal } \\
\text { yang berbeda }\end{array}$ \\
\hline $\begin{array}{l}\text { Keterincian/ } \\
\text { Elaborasi }\end{array}$ & $\begin{array}{c}\text { Mengembangk } \\
\text { an atau } \\
\text { memperkaya } \\
\text { gagasan orang } \\
\text { lain }\end{array}$ & $\begin{array}{c}\text { Siswa } \\
\text { mengembangkan } \\
\text { gagasan dari } \\
\text { guru/teman } \\
\text { dengan tepat }\end{array}$ & $\begin{array}{c}\text { Siswa } \\
\text { mengembangkan } \\
\text { gagasan dari } \\
\text { guru/teman } \\
\text { namun kurang } \\
\text { tepat }\end{array}$ & $\begin{array}{l}\text { Siswa } \\
\text { mengembangkan } \\
\text { gagasan dari } \\
\text { guru/teman } \\
\text { namun tidak tepat }\end{array}$ & $\begin{array}{l}\text { Siswa tidak } \\
\text { mengembangkan } \\
\text { gagasan dari } \\
\text { guru/teman }\end{array}$ \\
\hline
\end{tabular}

Untuk melengkapi penelitian ini dilakukan observasi melalui lembar observasi yang telah dibuat dengan mengamati kegiatan siswa maupun guru saat proses pembelajaran berlangsung yang diamati oleh seorang observer yang mengerti bagaimana sebuah proses pembelajaran berjalan dengan baik sesuai dengan rencana pembelajaran yang sudah dibuat sebelumnya.

\section{TEMUAN DAN PEMBAHASAN}

\section{Kreativitas Siswa Sebelum Menggunakan Metode Mind mapping}

Berdasarkan hasil observasi yang telah dilakukan maka ditemukan permasalahan mengenai kreativitas siswa yang tidak merata saat proses pembelajaran PKn berlangsung dan banyaknya siswa yang mendapatkan nilai di bawah KKM yaitu 70. Penelitian ini membandingkan sebelum dan sesudah treatment diberikan. Treatment yang digunakan adalah metode pembelajaran mind mapping untuk meningkatkan kreatifitas siswa. Pada saat guru tidak menggunakan metode pembelajaran mind mapping, dari 25 orang sisw, terdapat 7 orang siswa memiliki kreativitas yang baik yaitu $E, F, C, H, I, T, O$. Delapan belas (18) orang siswa lainnya memiliki kreativitas kurang baik yaitu $A, X, Z, L, J, N, B, G, P, R, U, S$, $P, Q, U, W, M, D$.

Hasil data nilai tersebut dapat di lihat dalam Tabel 2.

Tabel 2. Data Nilai Kreativitas Siswa Sebelum Menggunakan Metode Mind mapping

\begin{tabular}{ccc}
\hline Nama Siswa & $\begin{array}{c}\text { Sebelum menggunakan } \\
\text { metode }\end{array}$ & Keterangan \\
\hline C & 75 & Tuntas \\
E & 75 & Tuntas \\
F & 75 & Tuntas \\
H & 75 & Tuntas \\
I & 75 & Tuntas \\
0 & 75 & Tuntas \\
\hline
\end{tabular}


Tabel 2. Lanjutan

\begin{tabular}{ccc}
\hline Nama Siswa & $\begin{array}{c}\text { Sebelum menggunakan } \\
\text { metode }\end{array}$ & Keterangan \\
\hline T & 75 & Tuntas \\
\hline M & 67 & Tidak Tuntas \\
Q & 67 & Tidak Tuntas \\
U & 67 & Tidak Tuntas \\
Y & 67 & Tidak Tuntas \\
A & 67 & Tidak Tuntas \\
K & 58 & Tidak Tuntas \\
P & 58 & Tidak Tuntas \\
W & 58 & Tidak Tuntas \\
B & 58 & Tidak Tuntas \\
G & 50 & Tidak Tuntas \\
L & 50 & Tidak Tuntas \\
R & 50 & Tidak Tuntas \\
V & 50 & Tidak Tuntas \\
X & 50 & Tidak Tuntas \\
J & 50 & Tidak Tuntas \\
N & 42 & Tidak Tuntas \\
S & 42 & Tidak Tuntas \\
\hline Jumlah & 42 & Tidak Tuntas \\
\hline Nilai Rata-Rata & 1470 & \\
\hline Siswa Yang Tuntas & 59 & \\
\hline Siswa Yang Tidak Tuntas & 7 & \\
\hline Persentase Ketuntasan Belajar & 18 & \\
\hline Salasal
\end{tabular}

Sumber: Hasil penilaian siswa dari guru kelas MI Miftahul Falah

Siswa dinyatakan tuntas jika telah mencapai nilai $\geq 70$. Untuk melihat ketuntasan pembelajarannya dihitung dengan rumus sebagai berikut:

$$
S=\frac{9}{12} \times 100=75
$$

Dengan perhitungan ini siswa $\mathrm{C}$ dinyatakan tuntas dalam proses pembelajaran di kelas walaupun guru hanya menggunakan metode konfensional, ceramah dan tanya jawab saja. Lalu dari data nilai Tabel 1 dapat diketahui bahwa nilai rata-rata yang diperoleh oleh siswa adalah $28 \%$ dengan perhitungan sebagai berikut:

$$
\mathrm{X}=\frac{\sum x}{N}=\frac{1470}{25}=59
$$

Hasil kreativitas siswa pada proses pembelajaran sebelum menggunakan metode mind mapping, dapat dilihat dari tabel dibawah ini yang menunjukan bahwa hasil kreativitas siswa di kelas VI ini masih banyak sekali siswa yang belum mencapai nilai ketuntasan dan masih banyak siswa yang mendapat nilai dibawah KKM yang sudah ditentukan oleh sekolah/guru. Hasil tersebut dapat dilihat dalam Tabel 3. 
Tabel 3. Tingkat Penguasaan Kreativitas Siswa sebelum Menggunakan Metode Mind mapping

\begin{tabular}{cccc}
\hline Tingkat penguasaan & $\begin{array}{c}\text { Jumlah peserta } \\
\text { didik }\end{array}$ & Persentase & Keterangan \\
\hline $86-100$ & & & Sangat Baik \\
$76-85$ & 12 & $48 \%$ & Baik \\
$60-75$ & 4 & $16 \%$ & Cukup \\
$55-59$ & 9 & $36 \%$ & Kurang \\
$0-54$ & $9 u r a n g$ Sekali \\
\hline
\end{tabular}

Sumber: Hasil penilaian siswa dari guru kelas MI Miftahul Falah

Berdasarkan perhitungan persentase belajar ketuntasan klasikal dapat dilihat melalui perhitungan sebagai berikut:

$$
\begin{gathered}
\text { KK }=\frac{\text { jumlah siswa yang memperoleh nilai } \geq 70}{\text { jumlah selururh siswa }} \times 100 \% \\
=\frac{7}{25} \times 100 \%=28 \%
\end{gathered}
$$

Berdasarkan Tabel 3 dapat dilihat bahwa persentase ketuntasan kreativitas siswa MI Miftahul Falah ini masih belum ada satupun yang dinyatakan baik. Dari data tersebut bisa dilihat bahwa kreativitas siswa diantarannya 48\% dari 12 orang siswa dinyatakan cukup, lalu $16 \%$ dari 4 orang siswa dinyatakan kurang, dan $36 \%$ dari 9 orang siswa dinyatakan kurang sekali dari jumlah seluruh siswa 25 orang dalam satu kelas tersebut. Maka siswa kelas VI MI Miftahul Falah ini belum mencapai ketuntasan belajar dan perlu adanya perbaikan agar hasilnya lebih meningkat.

\section{Proses Penerapan Metode Mind Mapping untuk Meningkatkan Kreativitas Siswa}

Mind mapping atau peta pikiran merupakan suatu teknik penyusunan catatan, gagasan atau ide-ide pikiran yang dapat digunakan untuk mempermudah pemahaman dalam suatu pembelajaran yang dicatat denga kreatif, efektif, dan akan memetakan pikiran-pikiran. Selain itu juga mind mapping menggunakan kata kunci bebas, simbol, gambar dan biasanya menggambarkan secara kesatuan dengan menggunakan teknik pohon.

Syam dan Ramlah (2015) menjelaskan bahwa mind mapping memberikan beberapa keunggulan, yaitu: 1) Dapat mempermudah untuk mengingat sesuatu; 2) Memudahkan untuk mengingat dan menghafal akan lebih cepat; 3) Kerja otak semakin maksimal; 4) Meningkatkan kreativitas, lebih sederhana, dan sangat mudah untuk dikerjakan; 5) Mempermudah mendapatkan informasi, ide, dan gagasan untuk dapat dijelaskan. Adapun kelamahan metode mind mapping menurut Shoimin (2016), yaitu: 1) Yang terlibat hanya siswa yang aktif saja; 2) Hanya sebagian siswa yang belajar; 3) Jumlah detail informasi tidak dapat dimasukkan.

Ada beberapa langkah yang digunakan dalam metode mind mapping dalam kegiatan pembelajaran, yaitu: 1) Menyampaikan tujuan pembelajaran; 2) Menyajikan materi; 3) Siswa dibagi ke dalam beberapa kelompok; 4) Siswa 
memulai menyusun peta pikiran atau mind mapping; 5) Siswa mempresentasikan hasil diskusi kelompok di depan kelas; 6) Siswa menyampaikan kesimpulan.

Dalam kegiatan belajar proses penerapan mind mapping dapat meningkatkan kreativitas siswa karena pada dasarnya cara kerja mind mapping melibatkan cara kerja dasar otak yang tersusun lebih bercabang-cabang seperti pohon. Pola ini dapat mempermudah proses mengingat pada setiap apa yang dipelajari. Siswa dapat tertarik untuk membuat gambar-gambar atau warna-warna pada mind mapping agar terlihat lebih bagus dan menarik. Dalam proses pembelajaran di kelas siswa sangat antusias mengikuti proses pembelajaran menggunakan metode mind mapping, karena mereka lebih bebas berkreasi dalam mengerjakan tugas yang diberikan guru dan lebih mudah untuk memecahkan permasalahan yang diberikan guru.

\section{Kreativitas Siswa Setelah Menggunakan Metode Mind mapping}

Berdasarkan hasil observasi yang telah dilakukan pada saat proses pembelajaran PKn berlangsung dengan menggunakan metode mind mapping kreativitas siswa mengalami peningkatan dalam proses dan hasil pembelajaran yang dilakukan. Hasil tersebut dapat di lihat dari sebuah mind mapping yang dijadikan guru sebagai tolak ukur penilaian dalam proses pembelajaran tersebut dengan menggunakan penilaian rubrik yang terdiri dari 4 aspek penilaian dan data nilai tersebut dapat dilihat dalam Tabel 4.

Tabel 4. Data Nilai Setelah Menggunakan Metode Mind mapping

\begin{tabular}{ccc}
\hline Nama Siswa & $\begin{array}{c}\text { Sesudah Menggunakan } \\
\text { Metode }\end{array}$ & Keterangan \\
\hline C & 83 & Tuntas \\
D & 83 & Tuntas \\
E & 83 & Tuntas \\
I & 83 & Tuntas \\
O & 83 & Tuntas \\
Q & 83 & Tuntas \\
R & 83 & Tuntas \\
S & 83 & Tuntas \\
T & 83 & Tuntas \\
A & 75 & Tuntas \\
H & 75 & Tuntas \\
J & 75 & Tuntas \\
N & 75 & Tuntas \\
P & 75 & Tuntas \\
U & 75 & Tuntas \\
W & 75 & Tuntas \\
Y & 75 & Tuntas \\
B & 75 & Tuntas \\
G & 67 & Tidak Tuntas \\
K & 67 & Tidak Tuntas \\
\hline
\end{tabular}


Tabel 4. Lanjutan

\begin{tabular}{ccc}
\hline Nama Siswa & $\begin{array}{c}\text { Sesudah Menggunakan } \\
\text { Metode }\end{array}$ & Keterangan \\
\hline L & 67 & Tidak Tuntas \\
M & 67 & Tidak Tuntas \\
X & 67 & Tidak Tuntas \\
M & 67 & Tidak Tuntas \\
V & 65 & Tidak Tuntas \\
\hline Jumlah & 1905 & \\
\hline Nilai Rata-Rata & 76,2 & \\
\hline Siswa Yang Tuntas & 18 & \\
\hline Persentase Kang Tidak Tuntas & 7 & \\
\hline Sumber: Hasil penilaian siswa dari guru kelas Ml Miftahul Falah &
\end{tabular}

Siswa dinyatakan tuntas jika telah mencapai nilai $\geq 70$ sebagai contohnya siswa dapat dilihat dari salah satu siswa yaitu $Q$, untuk melihat ketuntasan pembelajarannya dapat dibuktikan dengan perhitungan sebagai berikut:

$$
S=\frac{10}{12} \times 100=83,3
$$

Dengan perhitungan ini siswa $Q$ dinyatakan tuntas dalam proses pembelajaran di kelas setelah guru menggunakan metode mind mapping ini dibandingkan dengan menguunakan metode konvensional seperti siswa $Q$ ia mengalami peningkatan hasil yang lumayan besar untuk data nilai pembelajaran PKn. Lalu dari data nilai tabel 3 dapat diketahui bahwa nilai rata-rata yang diperoleh oleh siswa adalah $68 \%$ dengan perhitungan sebagai berikut:

$$
X=\frac{\sum x}{N}=\frac{1905}{25}=72 \%
$$

Hasil kreativitas siswa pada proses pembelajaran dengan menggunakan metode mind mapping ini, dapat dilihat dari tabel dibawah ini yang menunjukan bahwa hasil kreativitas siswa di kelas VI ini sudah meningkat dan mencapai nilai ketuntasan dan sudah banyak siswa yang mendapat nilai atas KKM yang sudah ditentukan oleh sekolah/guru. Hasil tersebut dapat dilihat dalam Tabel 5.

Tabel 5. Tingkat Penguasaan Kreativitas Siswa Sesudah Menggunakan Metode Mind Mapping

\begin{tabular}{cccc}
\hline $\begin{array}{c}\text { Tingkat } \\
\text { penguasaan }\end{array}$ & Jumlah peserta didik & Persentase & Keterangan \\
\hline $86-100$ & & & \\
$76-85$ & 10 & $40 \%$ & Sangat Baik \\
$60-75$ & 15 & $60 \%$ & Baik \\
$55-59$ & & & $\begin{array}{c}\text { Cukup } \\
\text { Kurang } \\
0-54\end{array}$ \\
\hline
\end{tabular}

Sumber: Hasil penilaian siswa dari guru kelas MI Miftahul Falah 
Berdasarkan perhitungan persentase belajar ketuntasan klasikal dapat dilihat melalui perhitungan sebagai berikut:

$$
\begin{gathered}
\text { KK }=\frac{\text { jumlah siswa } \text { yang memperoleh nilai } \geq 70}{\text { jumlah selururh siswa }} \times 100 \% \\
=\frac{18}{25} \times 100 \%=72 \%
\end{gathered}
$$

Jumlah ini diperoleh dari hasil perhitungan kinerja siswa mengerjakan mind mapping, peneliti melihat bahwa metode ini menyebabkan kenaikan yang cukup bagus untuk melihat kreativitas siswa karena metode ini menunjang pengembangan proses kreativitas para siswa dengan menggunakan stimulus menggunakan percampuran warna sesuai keinginannya sendiri, lalu gambar yang sesuai dengan materi, dan teks yang mudah dipahami siswa dengan materi yang disampaikan.

Berdasarkan Tabel 5 dapat dilihat bahwa persentase ketuntasan kreativitas siswa kelas VI MI Miftahul Falah ini sudah bisa dinyatakan baik karena dari data diatas telah dibuktikan bahwa nilai kreativitas siswa sudah meningkat. Dari data tersebut bisa dilihat bahwa kreativitas siswa yang meningkat diantarannya $40 \%$ dari 10 orang siswa dinyatakan baik, lalu $60 \%$ dari 15 orang siswa dinyatakan cukup, dan sudah tidak ada lagi siswa yang mendapatkan nilai dibawah KKM dari jumlah seluruh siswa 25 orang dalam satu kelas tersebut setelah menggunakan metode pembelajaran mind mapping. Maka siswa kelas VI MI Miftahul Falah ini sudah dapat mencapai ketuntasan belajar dan hasilnya sudah lebih meningkat.

Berdasarkan penelitian terdahulu yang dilakukan, metode mind mapping dapat meningkatkan kreativitas siswa seperti pada penelitian Sukawati (2016) yang berjudul Peningkatan Siswa Dalam Menulis Cerpen Melalui Metode Pemetaan Pikiran (Mind mapping) yang dilakukan oleh siswa kelas X SMPN 14 Bandung. Dapat disimpulkan bahwa hasil penelitian menunjukkan bahwa perencanaan pembelajaran menulis cerpen dengan metode mind mapping cukup efektif meningkatkan kreativitas siswa dalam menulis cerpen. Pembelajaran menulis cerpen dengan menggunakan metode mind mapping dilaksanakan dalam dua siklus. Sejak proses kreatif membuat peta pikiran berlangsung, siswa sudah memahami secara mendalam tentang ide yang akan dituangkan dalam cerpen secara utuh. Selama pembelajaran di kelas, metode mind mapping telah mampu memunculkan perilaku siswa yang lebih positif. Siswa cenderung lebih aktif dan kreatif dalam bertanya dan mengemukakan gagasan. Suasana kelas pun menjadi lebih hidup. Kemampuan siswa dalam menulis cerpen dengan metode mind mapping semakin meningkat. Hasil analisis menunjukkan bahwa skor dan nilai yang dihasilkan mengalami peningkatan mulai dari 3,5\% sampai dengan $43,5 \%$. Meskipun hasil analisis menunjukkan tidak semua siswa mengalami peningkatan pada setiap kriteria, tetapi secara keseluruhan persentase nilai meningkat.

\section{KESIMPULAN}

Berdasarkan observasi yang telah kami lakukan dan hasil yang sudah dipaparkan sebelumnya, maka dapat disimpulkan bahwa metode mind mapping dapat meningkatkan kreativitas siswa dalam proses pembelajaran PKn di MI Miftahul Falah kelas VI ini. Dalam pemaparan tersebut sudah dijelaskan bahwa nilai 
siswa sebelum menggunakan metode pembelajaran itu menghasilkan nilai yang cukup rendah, ketika proses pembelajarannya menggunakan metode mind mapping ternyata mampu meningkatkan hasil kreativitas pada siswa.

Dari hasil data tersebut dapat disimpulkan bahwa penerapan metode mind mapping dapat meningkatkan kreativitas siswa, dengan demikian metode ini dapat dicobakan lebih lanjut untuk berbagai bidang ilmu lain apakah mempunyai kontribusi yang sama dalam meningkatkan kreativitas siswa.

\section{REFERENSI}

Betaubun, Since L., Agus K. H., Adi S., Ratna P. \& Yunarlianto P. (2018). Metode Mind Mapping Untuk Meningkatkan Kreativitas Menulis Dan Hasil Belajar Siswa Pada Materi Kesehatan. Musamus Journal Of Primary Education, Vol. 1, No 1.

Darusman, R. (2014). Penerapan Metode Mind Mapping (peta pikiran) Untuk Meningkatkan Kemampuan Berpikir Kreatif Matematik siswa SMP. Infinity Journal, 3(2), 164-173.

Fauziah, D. (2017). Penerapan Model Mind Map Untuk Meningkatkan Kreativitas Dan Pemahaman Siswa Pada Materi Sejarah Kerajaan Isam Di Indonesia. Mimbar Sekolah Dasar, Vol. 4, No 2. Ejournal Upi Bandung

Hermawan, Iwan. (2019) Metodologi Penelitian Pendidikan. Kuningan: Hidayatul Quran.

Mulyasa, E. (2013). Pengembangan dan Implementasi Kurikulum 2013. Yogyakarta: Remaja Rosdakarya.

Pamungkas, A., Bambang S., \& Suharto L. (2017). Implementasi Model Pembelajaran IPA Berbasis Kearifan Lokal untuk Meningkatkan Kreativitas dan Hasil Belajar Siswa. Jurnal Inovasi Pendidikan IPA, Vol. 3, No 2. Universitas Negeri Yogyakarta.

Prastyo, A. (2016). Pengaruh Metode Mind Mapping Terhadap Kreativitas Belajar Siswa Kelas V Pada Mata Pelajaran Matematika Di Sd Negeri Banyuanyar 1 Surakarta Tahun Pelajaran 2016/2017. Jurnal PGSD. Uviversitas Slamet Riyadi.

Sukawati, S. (2016). Peningkatan Siswa Dalam Menulis Cerpen Melalui Metode Pemetaan Pikiran (Mind Mapping). Jurnal Ilmiah Program Pendidikan Bahasa dan Sastra Indonesia, Vol 5, No 1. STKIP Siliwangi.

Shoimin, A. (2016). 68 Model Pembelajaran Inovatif dalam Kurikulum 2013. Cetakan ke-2. Jakarta: Ar-Ruzz Media.

Sitepu, A. (2019). Pengembangan Kreativitas Siswa. Guepedia.

Syam, N. \& Ramlah Ramlah. (2015). Penerapan Model Pembelajaran Mind Mapping Dalam Meningkatkan Hasil Belajar Pada Mata Pelajaran IImu Pengetahuan Sosial Siswa Kelas IV SDN 54 Kota Parepare. Jurnal Publikasi Pendidikan, Vol. V, No 3 Tahun 2015. Univeritas Negeri Makassar. 
Wulandari, F. A., Mawardi \& Krisma W. W. (2019). Peningkatan Keterampilan Berpikir Kreatif Siswa Kelas 5 Menggunakan Model Mind Mapping. Jurnal IImiah Sekolah Dasar, Vol. 3, No 1. Universitas Kristen Satya Wacana Indonesia

Yuniharto, B. S. \& Maria Melani I. S. (2019). Peningkatan Minat Belajar dan Kreativitas Belajar Siswa Kelas IIIA SDN Maguwoharjo I Melalui Model Pembelajaran Kooperatif Tipe GI Pada Materi Pertumbuhan dan Perkembangan Tumbuhan. Jurnal Pendidikan Guru Sekolah Dasar, Vol. 1, No 2. Universitas Kristen Toraja. 